\title{
PELATIHAN KETERAMPILAN MINDFUL PARENTING TERHADAP POLA PENGASUHAN ANAK USIA DINI DI TK ISLAM RAUDHATUL JANNAH
}

\author{
Aminah, Ainun Heiriyah, Sabit Tohari, dan Mahfuz \\ Fakultas Keguruan Dan Ilmu Pendidikan, Universitas Islam Kalimantan \\ Email : aminah.tp80@gmail.com
}

\begin{abstract}
ABSTRAK
Tumbuh kembang pada anak usia dini sangat penting untuk diketahui oleh orang tua. Mindful parenting merupakan salah satu cara pola pengasuhan terhadap anak usia dini dimana orang tua mampu menghargai tindakan dan pendapat anak, mampu menjalankan hubungan yang harmonis kepada anak dan mampu melaksanakan peran sebagai orang tua. Penyebab munculnya masalah bagi orang tua di seputar pengasuhan anak diantaranya adalah atribusi negatif orangtua terhadap perilaku anak, kontrol kemarahan yang rendah pada orangtua, dan kurangnya pengetahuan orang tua tentang pengasuhan anak sehingga mereka mengalami kesulitan dan berdampak pada hubungan orang tua dengan anak. Pada dasarnya kepribadian anak terbentuk dari bagaimana pola asuh yang dilakukan oleh orangtuanya. Namun sayangnya banyak orangtua yang tidak menyadari hal tersebut. Permasalahan yang dihadapi oleh mitra disebabkan karena kurangnya pemahaman orang tua tentang keterampilan yang diperlukan dalam pola asuh anak usia dini dan kurangnya keterampilan orang tua dalam pengasuhan anak dengan mindful parenting. Tujuan dari kegiatan pengabdian kepada masyarakat ini diharapkan mampu memberikan wawasan dan pengetahuan para orang tua (ibu) tentang keterampilan mindful parenting yang diperlukan dalam pola asuh anak usia dini sehingga orang tua dapat membangun komunikasi yang efektif untuk menciptakan pengasuhan positif. Metode yang digunakan adalah dengan memberikan materi, pelatihan, dan evaluasi. Hasil dari kegiatan ini secara umum gambaran keterampilan Mindful Parenting orangtua siswa sebelum dilaksanakan pelatihan berada pada kategori rendah dengan peroleh rata-rata 13.13, setelah dilakukan pelatihan Mindful Parenting secara umum gambaran keterampilan orangtua siswa mengalami peningkatan dengan rata-rata 23.26 yang termasuk dalam kategori sedang.
\end{abstract}

Kata Kunci : Mindful Parenting, Pola Asuh Anak Usia Dini

\section{PENDAHULUAN}

Orang tua merupakan pihak yang tidak dapat dipisahkan dari proses pertumbuhan dan perkembangan pada anak usia dini karena orangtua merupakan orang yang paling dekat dengan anak. Peran orang tua dalam membentuk tumbuh kembang anak merupakan suatu hal yang sangat penting. Tumbuh kembang pada anak usia dini sangat penting untuk diketahui oleh orangtua. Ada beberapa alasan mengapa orangtua harus mempelajari perkembangan anak usia dini, seperti yang diutarakan oleh Janet Black dkk (dalam Suyadi, 2013). Pertama, pengetahuan tentang tumbuh-kembang anak usia dini dapat memberikan pengertian dan pemahaman pada diri sendiri (Self-under standing). Kedua, 
pengetahuan tentang tumbuh-kembang bagi orang tua, para guru dapat membantu anak untuk memberi layanan edukasi secara optimal. Ketiga, adanya upaya para ahli mempelajari tumbuhkembang anak usia dini untuk belajar terus menerus (is an on going process) pada prinsipnya, para pakar psikologi sependapat bahwa pengalaman anak pada usia dini membawa akibat pada masa kehidupan yang akan datang, bahkan seorang ahli psikologi perkembangan, Elezabetjh B. Hurlocke (Dalam Suyadi, 2013) menyatakan bahwa :

"Kenakalan remaja bukanlah fenomena baru dari masa remaja melainkan suatu lanjutan dari pola perilaku asosiasi yang mulai pada masa kanak-kanak. Semenjak usia 2-3 tahun ada kemungkinan anak yang kelak menjadi remaja nakal”. (Hurlock, 1993)

Senada dengan pernyataan Hurlock tersebut, seorang ahli pendidikan, Ahmad Tafsir, menyatakan bahwa anak yang tidak dikembangkan aspek moral-agamanya kelak di masa dewasa akan menjadi orang yang relatif sulit untuk dididik moralitas dan keagamaannya (Ahmad Tafsir, 2003).

Merujuk pendapat para pakar yang telah dikemukakan tersebut jelas bahwa mempelajari tumbuh-kembang anak usia dini memberi keuntungan bagi orang dewasa, khususnya orang tua.

Setiap orang tua tentunya mempunyai pola asuh yang berbedabeda. Pola asuh adalah cara pendekatan orang dewasa kepada anak dalam memberikan bimbingan, arahan, pengaruh, dan pendidikan supaya anak menjadi dewasa dan mampu berdiri sendiri. Menurut Rifda El Fiah (2017) pada prinsipnya pola asuh ada tiga macam yaitu : pola asuh otoriter, dimana cara pendekatan atau pengasuhan yang berciri keras, disiplin yang tinggi, dan cenderung otoriter dari orangtua agar anak menjadi penurut, tertib dan tidak melawan. Akibatnya anak tidak mempunyai inisiatif, tidak pernah kreatif, dan takut salah. Anak tidak banyak kemauan dan menerima apa adanya, bahkan anak sering merasa tertekan, akhirnya tidak mengalami pertumbuhan dan perkembangan secara wajar. Apalagi kalau sering disalahi dan dimarahi oleh orangtuanya. Akibat yang lain anak menjadi penakut dan mempunyai rasa rendah diri. Pola asuh permisif, dimana pola asuh ini bersifat lunak. Anak diberikan kebebasan, sehingga akan bertumbuh dan 
berkembang secara normal. Ramburambu yang diberikan tidak terlalu banyak bahkan sedikit sekali sehingga anak merasa tidak takut, lalu bertindak atas dasar kemauan sendiri. Yang terakhir pola asuh demokratis dimana pola asuh ini menekankan pada pemberian kesempatan terhadap anak agar tumbuh dan berkembang secara wajar, tetapi penih dengan pemantauan dan pengawasan, anak diberi hak untuk mengeluarkan pendapat, ususl, saran, dan inisiatif, tetapi keputusan ada pada orangtua. Hak anak didengar, dihargai, dan diakui.

Menurut Duccan, (dalam Pathah Pajar Mubarok, 2016), mindful parenting dapat diartikan sebagai kesadaran orangtua dalam memberikan perhatian, bertujuan dan tidak memberikan label atau penilaian negatif dari setiap pengalaman anak. Mindful parenting merupakan salah satu cara pola pengasuhan terhadap anak usia dini dimana orangtua mampu menghargai tindakan dan pendapat anak, mampu menjalankan hubungan yang harmonis kepada anak dan mampu melaksanakan peran sebagai orang tua. Dalam konsep mindful parenting ini orangtua diharapkan mampu untuk belajar bagaimana mengendalikan diri, mampu menghargai dan mampu memahami kondisi anak. Menurut Melly Kiong (2015) praktisi mindful parenting terdapat lima dimensi yang perlu diperhatikan dalam pola asuh ini, yaitu (1) Mendengarkan dengan perhatian penuh, (2) Tidak menghakimi, (3) Kesadaran dalam mengendalikan emosi diri, (4) Kesadaran dalam mengendalikan emosi diri, dan (5) Kasih sayang kepada anak.

Menurut Sanders, (dalam Pathah Pajar Mubarok, 2016), penyebab munculnya masalah bagi orang tua di seputar pengasuhan anak diantaranya adalah atribusi negatif orang tua terhadap perilaku anak, kontrol kemarahan yang rendah pada orang tua, dan kurangnya pengetahuan orang tua tentang pengasuhan anak sehingga mereka mengalami kesulitan dan berdampak pada hubungan orang tua dengan anak. Pola pengasuhan yang negatit juga akan berdampak pada tingkat kepercayaan diri anak, begitu besar fungsi dan peranan kepercayaan diri pada kehidupan individu. Tanpa adanya rasa percaya diri yang tertanam dengan kuat di dalam jiwa individu, pesimisme dan rasa rendah diri akan dengan mudah menguasai dirinya. Tanpa dibekali kepercayaan diri yang 
mantap sejak dini, maka individu akan tumbuh menjadi pribadi yang lemah. Menurut Mastuti dalam Jarkawi (2016) menyatakan "kepercayaan diri adalah sikap positif seorang individu yang memampukan dirinya untuk mengembangkan penilaian positif baik terhadap diri sendiri maupun terhadap lingkungan/situasi yang dihadapinya”. Untuk membentuk interaksi perlu adanya komunikasi yang baik antar manusia, karena apabila individu tidak dapat berkomunikasi dengan baik maka tidak akan terbentuk interaksi yang baik pula (Rachmayanie, 2020) jadi pada dasarnya kepribadian anak terbentuk dari bagaimana pola asuh dan komusikasi yang dilakukan oleh orang tuanya. Namun sayangnya banyak orang tua yang tidak menyadari hal tersebut.

\section{METODE PELAKSANAAN}

Bentuk kegiatan yang diselenggarakan yaitu serangkaian kegiatan yang akan dilaksanakan dalam bentuk materi, pelatihan, dan evaluasi yang meliputi:

1. Materi

Penyampaian materi mengenai Mindful Parenting Terhadap Pola Pengasuhan Anak Usia Dini
2. Pelatihan Mindful Parenting

Pelatihan (Training) adalah suatu proses melatih : kegiatan atau pekerjaan. Tujuan dari pelatihan ini adalah agar orang tua mempunyai keterampilan dalam pola pengasuhan anak. Pelatihan Mindful Parenting ini meliputi :

a. Bermain peran tentang pengasuhan yang positif.

b. Focus Group Discussion tentang permasalahan anak usia dini.

c. Reflection. Pada sesi ini orang tua menonton cuplikan film tentang berbagai macam sikap orang tua terhadap dirinya sendiri dalam mengasuh anak.

d. Skill review keterampilan mindful parenting.

3. Evaluasi

Kegiatan pengabdian kepada masyarakat yang telah dilaksanakan segera dilakukan proses evaluasi agar membantu pelaksana kegiatan dalam mencapai tujuan kegiatan yang diharapkan secara maksimal. Sasaran kegiatan ini adalah orang tua siswa/siswi TK Islam Rhaudatul Jannah. 


\section{HASIL DAN PEMBAHASAN}

Pengabdian kepada masyarakat yang dilaksanakan di TK Islam Raudhatul Jannah yang beralamat Jl.A.Yani Km 8 Komp. Palapan Indah RT.9 Blok J Kertak Hanyar. Kabupaten Banjar pada tanggal 01 Febuari 2019. Kegiatan Mindful Parenting ini dihadiri oleh hampir seluruh orang tua/wali murid TK islam Raudhatul jannah. Peserta yang hadir pada kegiatan ini berjumlah 27 orang.

$$
\text { Bentuk kegiatan yang }
$$
diselenggarakan yaitu serangkaian kegiatan yang dilaksanakan dalam bentuk materi, pelatihan mengenai perihal keterampilan Mindful Parenting dan evaluasi. Tujuan dari pelatihan ini adalah agar orang tua mempunyai keterampilan dalam pola pengasuhan anak.

Bentuk evaluasi dari kegiatan pengabdian kepada masyarakat ini dapat dilihat dari hasil kuesioner yang disebarkan kepada peserta kegiatan dan telah dianalisis serta dituangkan kedalam sebuah data di bawah ini:

Tabel 5.1 Kategori Interval Skor Rata-Rata Penilaian Pemahaman Peserta

\begin{tabular}{cc}
\hline Interval & Kategori \\
\hline $25-32$ & Tinggi \\
$17-24$ & Sedang \\
$8-16$ & Rendah \\
\hline
\end{tabular}

Sumber: data primer diolah (2020)

Secara umum gambaran keterampilan Mindful Parenting orangtua siswa sebelum dilaksanakan pelatihan berada pada kategori rendah dengan peroleh rata-rata 13.13. Setelah dilakukan pelatihan Mindful Parenting yang meliputi :

1. Bermain peran tentang pengasuhan yang positif.

2. Focus Group Discussion tentang permasalahan anak usia dini.
3. Reflection. Pada sesi ini orang tua menonton cuplikan film tentang berbagai macam sikap orang tua terhadap dirinya sendiri dalam mengasuh anak.

4. Skill review keterampilan mindful parenting.

Secara umum gambaran keterampilan orangtua siswa mengalami peningkatan dengan rata-rata 23.26 yang termasuk dalam kategori sedang. 
Gambaran keterampilan Mindful Parenting orangtua siswa dapat dilihat dari grafik 5.2

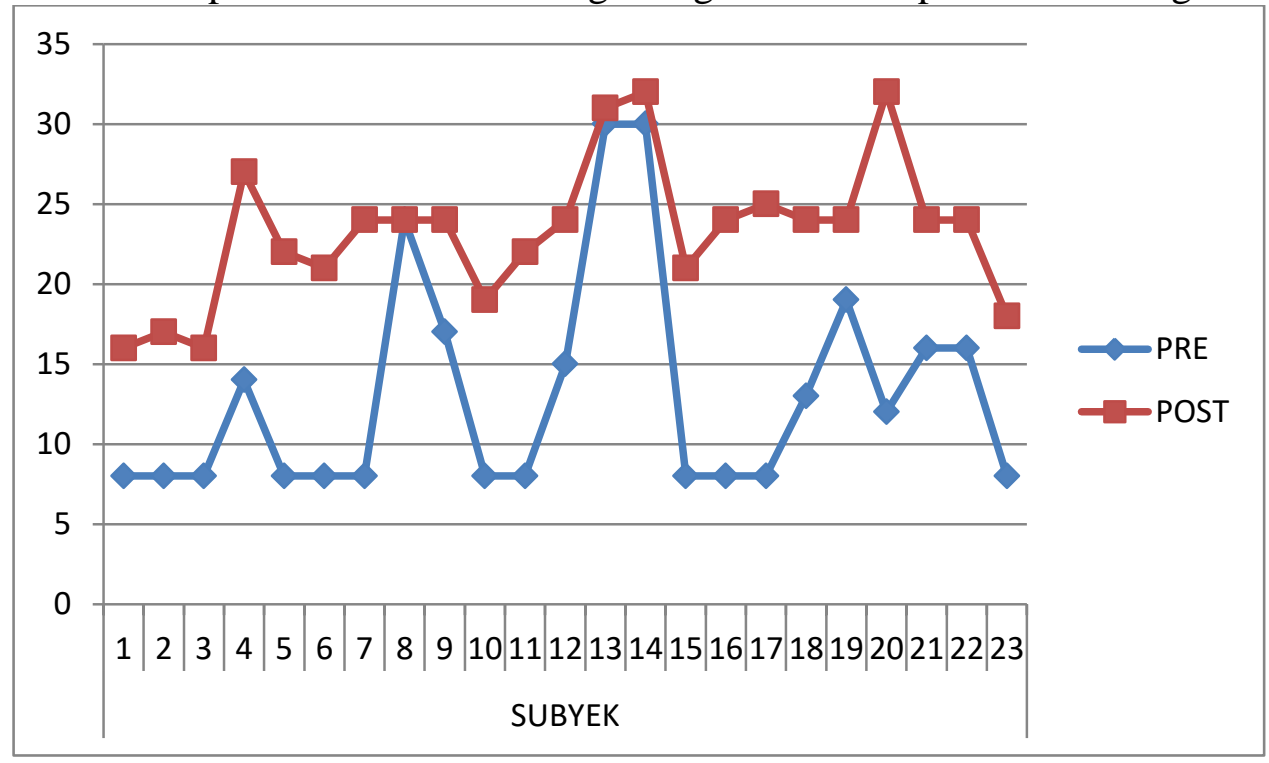

Grafik 5.2 gambaran pretest-posttest keterampilan mindful parenting

Hal ini berarti bahwa materi yang disampaikan benar-benar menjadi sebuah referensi tambahan dalam pola pengasuhan anak usia dini.

Diharapkan setelah kegiatan ini agar peserta kegiatan mampu melaksanakan dan mengaplikasikan keterampilan mindful parenting ini pada pola pengasuhan anak dalam kehidupan sehari-hari sesuai dengan perkembangan zaman.

\section{KESIMPULAN}

Pelaksanaan kegiatan berlangsung sangat baik dan berjalan dengan sukses. Hal ini terlihat dari keantusiasan para peserta disetiap sesi kegiatan. Kegiatan ini dihadiri oleh hampir seluruh orang tua siswa/siswi di
TK Islam Raudhatul Jannah yang berjumlah 27 orang.

Bentuk evaluasi dari kegiatan pengabdian kepada masyarakat ini setelah dianalisis secara umum gambaran keterampilan Mindful Parenting orangtua siswa sebelum dilaksanakan pelatihan berada pada kategori rendah dengan peroleh ratarata 13.13, setelah dilakukan pelatihan Mindful Parenting secara umum gambaran keterampilan orangtua siswa mengalami peningkatan dengan ratarata 23.26 yang termasuk dalam kategori sedang.

Hasil evaluasi menunjukkan terjadi peningkatan pemahaman orangtua terhadap Mindful Parenting sehingga diharapkan orangtua siswa/siswa mampu mengaplikasikan 
keterampilan Mindful Parenting ini dalam kehidupan sehari-hari terhadap pola pengasuhan anak.

\section{DAFTAR PUSTAKA}

El Fiah, Rifda. 2017. Bimbingan dan Konseling Anak Usia Dini. Jakarta: Kharisma Putra Utama Offset

Jarkawi \& Zanal, F (2016) Penyuluhan Tentang Cara Meningkatkan Kepercayaan Diri Siswa Dengan Fun Game Pada Musyawarah Guru Bimbingan Dan Konseling Mts Kota Banjarmasin. Jurnal Pengabdian Al-Ikhlas. Vol.2 No.1, Hal : 28-33

Kiong, melly. (2015). Mindfull Parenting.

Kemendikbud.
Rachmayanie, R \& Sulistiyana. (2020). Pelatihan Teknik Asertif Untuk Mengurangi Kecemasan Komunikasi Interpersonal Pada Siswa Kelas X Sma Negeri 12 Banjarmasin. Jurnal Pengabdian Al-Ikhlas. Vol.5 No.2, Hal: 126132

Mubarok, P. 2016. Program Pengasuhan Positif Untuk Meningkatkan Keterampilan Mindful Parenting Orangtua Remaja. Jurnal Ilmiah Psikologi. Vol.3, No 1, Hal: 35-50

Suyadi \& Maulidya Ulfa. 2013. Konsep Dasar PAUD. Bandung: PT. Remaja Rosda Karya Offset

Tafsir, Ahmad. 2005. Ilmu Pendidikan dalam perspektif islam, Cet. VI. Bandung: PT Remaja Rosdakarya. 